\title{
Tomasz Lesiów
}

Uniwersytet Ekonomiczny we Wrocławiu

e-mail: tomasz.lesiow@ue.wroc.pl

ORCID: 0000-0002-1284-5874

\section{Magdalena Kuchlewska}

Zespół Szkół Gastronomicznych nr 2 w Krakowie e-mail: magdar6@interia.pl

\section{ROLA PRZEKĄSEK W ŻYWIENIU CZLOWIEKA ZE SZCZEGÓLNYM UWZGLĘDNIENIEM PRZEKĄSEK MIECNYCH}

\section{THE ROLE OF SNACKS IN HUMAN NUTRITION WITH PARTICULAR REFERENCE TO MEAT SNACKS}

DOI: $10.15611 /$ nit.2020.36.07

JEL Classification: Q19

Streszczenie: Celem autorów pracy było przedstawienie roli przekąsek w codziennej diecie w Polsce i na świecie. Omówiono aktualny stan wiedzy na podstawie prowadzonych badań ankietowych w kraju i w ujęciu globalnym, z uwzględnieniem przekąsek zalecanych i niezalecanych w diecie człowieka dla różnych grup wiekowych. Spożywanie przekąsek ma duży udział w nawykach żywieniowych, szczególnie wśród nastolatków. Wiedza na temat wpływu zachowań żywieniowych związanych ze spożywaniem przekąsek na masę ciała i stan zdrowia ma kluczowe znaczenie dla określenia działań publicznych w zakresie promowania zdrowych nawyków żywieniowych. Wykazano, że preferencje smakowe względem przekąsek różnią się w zależności od regionu czy państwa. Zwrócono uwagę na dynamicznie rozwijający się sektor przekąsek mięsnych w Polsce i na świecie. Decyzje zakupowe dotyczące przekąsek powinny się opierać na wiedzy konsumentów, pozyskanej głównie w czasie edukacji szkolnej, a uzupełnionej informacjami ze środków masowego przekazu oraz na daleko idącej rozwadze/roztropności.

Słowa kluczowe: przekąski, nadwaga, częstotliwość spożywania, przekąski mięsne.

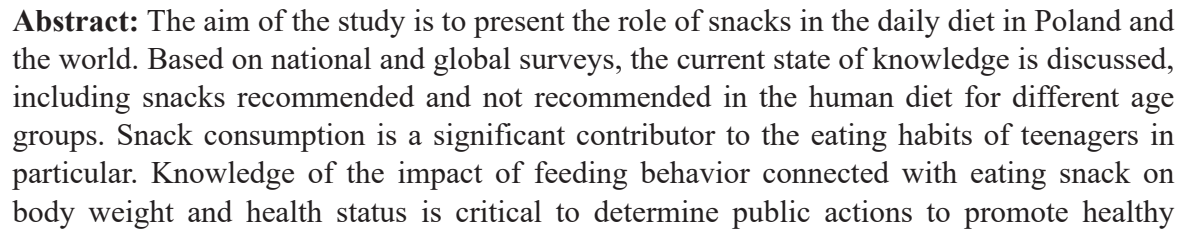


eating habits. Taste preferences for snacks have been shown to vary by region or country. The dynamically developing meat snacks sector in Poland and in the world was indicated. Purchasing decisions concerning snacks should be based on consumer knowledge, acquired mainly during school education, complemented by information from the mass media and a far-reaching consideration/prudence.

Keywords: snacks, overweight, frequency of eating, meat snacks.

\section{Wstęp}

Dietetycy zalecają spożywanie posiłków pięć razy dziennie, a przerwy pomiędzy nimi nie powinny być dłuższe niż 2-3 godziny. Taki rytm posiłków pozwala utrzymać właściwy poziom cukru we krwi przez cały dzień. W prawidłowej diecie przekąski między trzema głównymi posiłkami są konieczne, ich kaloryczność nie powinna jednak przekraczać $200 \mathrm{kcal}$ oraz powinny one być dobierane do stylu życia i aktywności (Hynek-Okonski, 2007).

Przekąską nazywa się produkt żywnościowy, którego nie traktuje się jako pełnego dania, lecz jako mały posiłek zaspokajający głód pomiędzy głównymi posiłkami.

Istnieje wiele kryteriów podziału przekąsek, najczęściej dzieli się je ze względu na: smak (słodkie, słone, pikantne), obróbkę termiczną, jakiej są poddawane (pieczone, smażone, ekstrudowane), wartość odżywczą (pełno- i niepełnowartościowe), główny składnik (skrobiowe, skrobiowo-mięsne, mięsne) (Kuchlewska, 2019).

Przekąski towarzyszą każdemu w codziennej diecie i są one nie do przecenienia, jeżeli ich wybór podąża za zaleceniami dietetyków. Wiedza konsumentów na temat przekąsek jest coraz szersza. Jednak wiele osób, opierając się na nieprawidłowych nawykach żywieniowych, naraża się na potencjalne niekorzystne konsekwencje zdrowotne wynikające ze spożywania przekąsek o nieodpowiedniej wartości odżywczej.

W literaturze krajowej można odnaleźć wiele doniesień na temat „zdrowych” przekąsek, zalecanych dla konsumentów w różnym wieku. Niewiele jest jednak informacji, jak zagadnienie wyboru i spożywania przekąsek prezentuje się w skali globalnej. Dlatego celem autorów pracy było przedstawienie roli przekąsek w codziennej diecie w Polsce i na rynku globalnym.

\section{Literatura krajowa dotycząca przekąsek}

W diecie zarówno dzieci, jak i dorosłych dominują przekąski w postaci batoników, ciast i ciasteczek, słodkich bułeczek, pączków, chipsów i paluszków. Spożywane są one chętnie, bo są nie tylko smaczne, ale również łatwo dostępne. Niestety produkty te wnoszą do diety duże ilości kalorii, tłuszczu i cukrów, niewiele natomiast dostarczają witamin i składników mineralnych (Internet 2). Najlepszymi przekąskami będą oczywiście te, które są jak najmniej przetworzone i dostarczają organizmowi cennych składników odżywczych. Produktami tymi są głównie owoce i warzywa, 
zarówno świeże, jak i suszone, mrożone oraz w formie wyciskanych soków (Bąkowska, Nijaka i Strażyńska, 2019). Warto jednak wybierać te owoce, które zawierają stosunkowo mało cukrów prostych w swoim składzie, a należą do nich m.in.: arbuz, kiwi, cytrusy, truskawki, maliny. Do wartościowych przekąsek zaliczyć można również chrupki kukurydziane, paluszki oraz inne podobnego typu produkty, które mają „,czysty” skład i nie zawierają zbędnych dodatków (głównie soli, cukru i jego pochodnych) (Górnicka, Frąckiewicz, Anyżewska i Brzezińska, 2016).

Listę przekąsek rekomendowanych w prawidłowo zaplanowanej diecie, w formie stanowiska, przygotował Zespół Ekspertów na spotkaniu towarzystw i instytutów naukowych zorganizowanym 22 września 2015 roku przez Komitet Nauki o Żywieniu Człowieka PAN oraz Polskie Towarzystwo Nauk Żywieniowych. Do produktów, które mogą być polecane jako zdrowe przekąski, zaliczono:

- świeże warzywa w formie nieprzetworzonej i jako sałatki,

- świeże owoce i produkty na ich bazie (np. musy, sałatki),

- mleczne produkty fermentowane, jak naturalne i smakowe jogurty, maślanki i serki homogenizowane.

Warzywa i owoce stanowią w diecie źródło witamin, składników mineralnych i błonnika. Natomiast mleczne produkty fermentowane są polecane ze względu na wysoką gęstość żywieniową, źródło białka i wapnia. Te trzy grupy produktów charakteryzują się dosyć niską kalorycznością, przy jednocześnie wysokiej wartości odżywczej.

Do zdrowych przekąsek zaliczono także pełnoziarniste produkty zbożowe, jak płatki i drobne ciasteczka pełnoziarniste, stanowiące źródło węglowodanów złożonych i błonnika pokarmowego; orzechy, bogate w składniki mineralne i korzystne dla zdrowia kwasy tłuszczowe, a także suszone owoce - źródło składników mineralnych i błonnika. $Z$ uwagi na wysoką wartość energetyczną promuje się jednak ich spożywanie w ograniczonej ilości.

Podkreślono również, że należy zmniejszać spożycie przekąsek o dużej wartości energetycznej i małej wartości żywieniowej, do których zaliczono słodycze, słone przekąski, ciasta i ciastka (Internet 4).

Zdrowe przekąski mogą być częścią prawidłowo zbilansowanej diety. Powinny nie tylko zaspokajać głód, ale także pozytywnie wpływać na pracę organizmu (Kazbieruk, 2020). Można do nich zaliczyć: banany (źródło węglowodanów, witamin - $\mathrm{B}_{6}$, składników mineralnych - potas), pomarańcze (zawierają naturalny cukier, są bogate $\mathrm{w}$ witaminę $\mathrm{C}$, dostarczają kwasu cytrynowego, są dobrym źródłem antyoksydantów), mango (cenne źródło witaminy $\mathrm{C}$ i E oraz potasu), marchew (źródło cukrów, $\beta$-karotenu, który działa jako antyoksydant i jest prekursorem witaminy A), brokuły (duża ilość składników odżywczych, dobre źródło cynku i wapnia, witaminy $\mathrm{B}_{5}$, kwasu foliowego), grzyby (powoli uwalniają energię, zawierają chrom, źródło witamin z grupy B), tuńczyka (dostarcza wielu składników odżywczych, jest bogaty w kwasy n-3 EPA i DHA), ostrygi (dostarczają protein, witamin z grupy B- $B_{12}$ i dużych ilości składników mineralnych - żelaza, jodu), wołowinę (bogate źródło białka i żelaza oraz kwasu linolowego), mleko (zawiera wapń, potas oraz witaminę E), jaja 
(bogate źródło białka, witamin z grupy B-B ${ }_{12}$ oraz witamin A, D i K, cynku, żelaza, fosfolipidów). Smaczną i zdrową przekąską mogą być także jabłka (bogate źródło błonnika i flawonoidów, zawierające wapń i krzem), warzywa, musy owocowe. Alternatywą mogą być chipsy owocowe lub warzywne, np. z buraków z dodatkiem przypraw. Ponadto przekąską może być baton na bazie płatków muesli z dodatkiem orzechów włoskich, które zawierają znaczne ilości wielonienasyconych kwasów thuszczowych, witaminę E, magnez, wapń i potas, lub z dodatkiem orzechów laskowych, pistacjowych, migdałów i orzechów arachidowych, zawierających jednonienasycone kwasy tłuszczowe. Zalecane jest także spożywanie pestek dyni będących źródłem kwasów tłuszczowych n-6, magnezu, fosforu, cynku i potasu oraz witaminy E i $\beta$-karotenu, ziaren słonecznika - źródła białka, magnezu, cynku, witaminy E oraz rodzynek zawierających znaczne ilości wapnia. Nieco więcej kreatywności wymaga wykonanie koreczków warzywnych z dodatkiem sera białego, cienkiego plasterka sera żółtego, sera feta i chudych wędlin oraz koreczków owocowych - owoców pokrojonych w kostkę i nabitych na wykałaczkę. Przekąskami cennymi dla naszego organizmu mogą być koktajle owocowe na bazie kefiru, maślanki lub mleka, naturalne soki, owocowe galaretki lub galaretki warzywno-mięsne z dodatkiem lub bez dodatku żelatyny. Smaczną przekąską mogą też być ruloniki z chudej wędliny, np. szynki wiejskiej, z zawiniętą w niej porcją chudego sera twarogowego (Bąkowska $i$ in., 2019; Kazbieruk, 2020; Mazowska, 2020).

Natomiast do niezdrowych przekąsek zalicza się: chipsy, białe bułki, pieczywo cukiernicze, żywność typu fast food, batony czekoladowe, cukierki, żelki, lizaki, dosładzane soki owocowe, słodzone napoje gazowane (Mazowska, 2020).

Wartość kaloryczną przekąsek oblicza się, mnożąc kaloryczność danej diety przez procentowy udział tego posiłku w całodziennej racji pokarmowej. Wartość kaloryczna przekąski nie powinna stanowić więcej niż 5-10\% całkowitej ilości kilokalorii spożywanych w ciągu dnia.

Hynek-Okonski (2007) podaje zestawy przekąsek na czas odchudzania, PMS (zespół napięcia przedmiesiączkowego), miesiączki, stresu, uprawiania sportu, wskazując na konieczność kontroli wartości odżywczej przekąsek tak, aby ich kaloryczność nie przekraczała $200 \mathrm{kcal}$. Przekąski powinny też być dostosowane do stylu życia i aktywności fizycznej.

Wśród gotowych przekąsek oferowanych przez sklepy wyróżnić można następujące: hummus jedzony $\mathrm{z}$ łodygami selera naciowego lub $\mathrm{z}$ chlebkiem razowym (może być również pieczywo chrupkie); zupy krem, surówki spożywane same lub z pieczywem razowym, owoce i warzywa (np. pomidorki koktajlowe), orzechy (niesolone i bez słodkich dodatków), suszone owoce, niesłodzone serki wiejskie/ jogurty/kefiry czy maślanki spożywane same lub z owocami i orzechami, chipsy warzywne (Lamont, 2018). Jeżeli w miejscu pracy jest wydzielona część kuchenna, warto zaopatrzyć się w minizapasy z płatków owsianych, miks sałat z warzywami, oliwę z oliwek i w krótkim czasie na miejscu przygotować zdrową sałatkę lub pożywną owsiankę. 
Na podstawie badań ankietowych przeprowadzonych wśród studentów różnych wydziałów Szkoły Głównej Gospodarstwa Wiejskiego w Warszawie Kosicka-Gębska i Gębski (2012) stwierdzili, że słone przekąski („snack food” - chipsy, paluszki/precelki, solone orzeszki, popcorn, krakersy, chrupki kukurydziane) są bardzo popularne wśród młodych konsumentów, mimo że nadmierne ich spożywanie, ze względu na znaczną kaloryczność i zawartość soli, ma negatywny wpływ na zdrowie. Respondenci deklarowali spożywanie słonych przekąsek podczas oglądania telewizji, na prywatkach oraz spotkaniach ze znajomymi (29\%, 25\% i 21\%), a także w mniejszym stopniu w kinie, w wolnej chwili, podczas pracy/nauki, między posiłkami oraz podczas wyjazdów ze znajomymi. Kryteriami wyboru słonych przekąsek przez studentów był smak, w mniejszym stopniu świeżość, a w niewielkim kształt, zapach i sposób krojenia produktu.

W badaniach ankietowych, przeprowadzonych m.in. przez firmę Mintel w 2014 r. na grupie tysiąca internautów w wieku minimum 16 lat, stwierdzono, że zdrowe przekąski są coraz ważniejsze w diecie Polaków. Głównymi czynnikami decydującymi o wyborze przekąsek przez respondentów były cena oraz ulubiony smak (po $55 \%$ odpowiedzi), to, że były one w ofercie promocyjnej (36\%), zaufanie, jakimi darzą daną markę (33\%), smak/marka lubiany/a przez całą rodzinę (29\%) oraz wyrazisty bądź oryginalny smak przekąski $(27 \%)$. Ponadto niemal co piąty respondent deklarował duże przywiązanie do walorów zdrowotnych kupowanych przekąsek, a najważniejszymi czynnikami zakupowymi były naturalne składniki (22\%), niska zawartość tłuszczu (21\%) i niska kaloryczność (19\%) produktu (Internet 6).

Podobne wyniki uzyskano w Centrum Badawczo-Rozwojowym BioStat ${ }^{\circledR}$ (Internet 5). W badaniu ankietowym z udziałem tysiąca respondentów, dotyczącym poznania opinii na temat rynku chipsów, stwierdzono, że respondenci, szczególnie osoby młode (do 35 roku życia), chętnie sięgają po słone przekąski, wśród których największą popularnością cieszą się chipsy. Respondenci wskazali, że najczęściej spożywają chipsy podczas spotkań towarzyskich (82\%) lub oglądania telewizji (29\%). Ponadto głównym kryterium wyboru był smak produktu, na co wskazało $93 \%$ respondentów, a w mniejszym stopniu marka (63\%), lojalność wobec konkretnego producenta (25\%). Aż 89\% uczestników ankiety miało świadomość niekorzystnego wpływu spożywania chipsów na zdrowie, $32 \%$ zadeklarowało, że czyta ich skład i stara się nabywać zdrowsze alternatywy tego produktu, np. chipsy o obniżonej zawartości tłuszczu (45\%), chrupiące przekąski z ciecierzycy lub soczewicy (34\%) lub suszone plasterki warzyw (25\%).

\section{Literatura zagraniczna na temat przekąsek}

Spożywanie przekąsek stanowi znaczący udział w nawykach żywieniowych nastolatków. Wśród przekąsek i fast foodów najpopularniejsze są chipsy, napoje bezalkoholowe, ciastka, czekoladki itp., a wśród napojów - herbata, kawa i inne napoje na bazie mleka. Ponieważ przekąski i fast foody są spożywane między posiłkami, 
zmniejszają apetyt na regularne, główne posiłki, co sprawia, że nastolatki są bardziej podatne na problemy żywieniowe niż jakakolwiek inna grupa wiekowa (Kulshrestha, Pant i Kulshrestha, 2017). Większość nastolatków spożywa przekąski tylko raz dziennie (Internet 3). Schemat ukazujący częstotliwość spożywania przekąsek przedstawiono na rys. 1 .

W kilku publikacjach przedstawiono potencjalny związek pomiędzy spożywaniem przekąsek a nadwagą i otyłością wśród dzieci i młodzieży. Nicklas, O’Neil i Fulgoni (2013) w przeprowadzonych badaniach ankietowych wykonanych w USA na populacji 14220 dzieci w wieku od 2-18 lat wykazali, że tylko 8\% dzieci nie spożywa przekąsek w ciągu dnia. Najczęstszą formą przekąsek były ciastka, ciasteczka i ciasta $(16 \%)$, następnie mleko pełne, sok pomarańczowy, produkty mięsne $(13 \%)$ oraz krakersy i słone przekąski (13\%). Skutkowało to większym spożyciem przez badanych błonnika, witamin $\mathrm{A}, \mathrm{C}, \mathrm{B}_{12}$ i $\mathrm{K}$, ryboflawiny, folianów, potasu, wapnia, cynku i magnezu, nasyconych kwasów tłuszczowych, tłuszczów stałych, dodanych cukrów i sodu. Stwierdzono także, że kilka zestawów przekąsek, z osiemnastu przebadanych, w porównaniu z brakiem przekąsek, miało wpływ na lepszą jakość diety i nie przyczyniało się do powstania nadwagi lub otyłości brzusznej.

Wang, Van der Horst, Jacquier, Afeiche i Eldridge (2018) stwierdzili, że u dzieci, w wieku 4-8 lat oraz 9-13 lat częstość występowania przekąsek i ich udział w całkowitej dziennej ilości energii i składników odżywczych były różne w kilku badanych krajach. Przekąski były najbardziej rozpowszechnione w Australii i USA (ponad 95\%) i stanowiły odpowiednio jedną trzecią i jedną czwartą całkowitego poboru energii (Total Energy Intake, TEI), następnie w Meksyku (76\%, 15\% TEI) i w Chinach $(65 \%, 10 \%$ TEI). W porównaniu z dziećmi w wieku 4-8 lat spożycie owoców i mleka było niższe u dzieci w wieku 9-13 lat, a w Chinach, Meksyku i w USA zaobserwowano tendencję wzrostową konsumpcji ciastek. Wskaźnik gęstości odżywczej dodanych cukrów i tłuszczów nasyconych był wyższy, szczególnie w Australii, Meksyku i USA. Wyniki sugerowały, że przekąski mogą być okazją do promowania spożycia owoców i warzyw we wszystkich krajach, szczególnie w przypadku starszych dzieci. Według wspomnianych autorów (Wang i in., 2018) wytyczne dotyczące przekąsek powinny się koncentrować na ograniczaniu spożycia przekąsek o wysokiej zawartości tłuszczów nasyconych i dodanych cukrów w przypadku Australii, Meksyku i USA, podczas gdy w Chinach - na zwiększeniu spożycia przetworów mlecznych.

Bo i in. (2014) nie stwierdzili związku między podwyższoną kalorycznością przekąsek, częstotliwością ich spożywania, wieczornym podjadaniem a nadwagą/ otyłością u młodzieży (11-13 lat) z włoskich gimnazjów. Przekąski mogą stanowić dobre źródło błonnika pokarmowego. Gdyby owoce i świeże warzywa były spożywane codziennie jako przekąski, łatwiej byłoby osiągnąć zalecane cele żywieniowe. Jednak przekąski raczej nie poprawiają jakości diety, ponieważ jest to zazwyczaj żywność o dużej gęstości energetycznej i wysokiej zawartości węglowodanów, pomimo niższej zawartości tłuszczu niż w głównych posiłkach. Młodzież charaktery- 


\section{JAK CZESTO POWINIENEM JEŚĆ?}

Nie ma ustalonych zasad dotyczących tego, kiedy należy jeść w ciągu dnia. Ogólnie rzecz biorąc, dla większości ludzi najlepiej jest zjeść śniadanie w ciągu pierwszej godziny po przebudzeniu, aby ustabilizować poziom cukru we krwi. Po śniadaniu najlepiej jest spróbować jeść wtedy, kiedy zaczynamy odczuwać głód: jeść powoli i przestać, zanim poczujemy się zbyt syci.

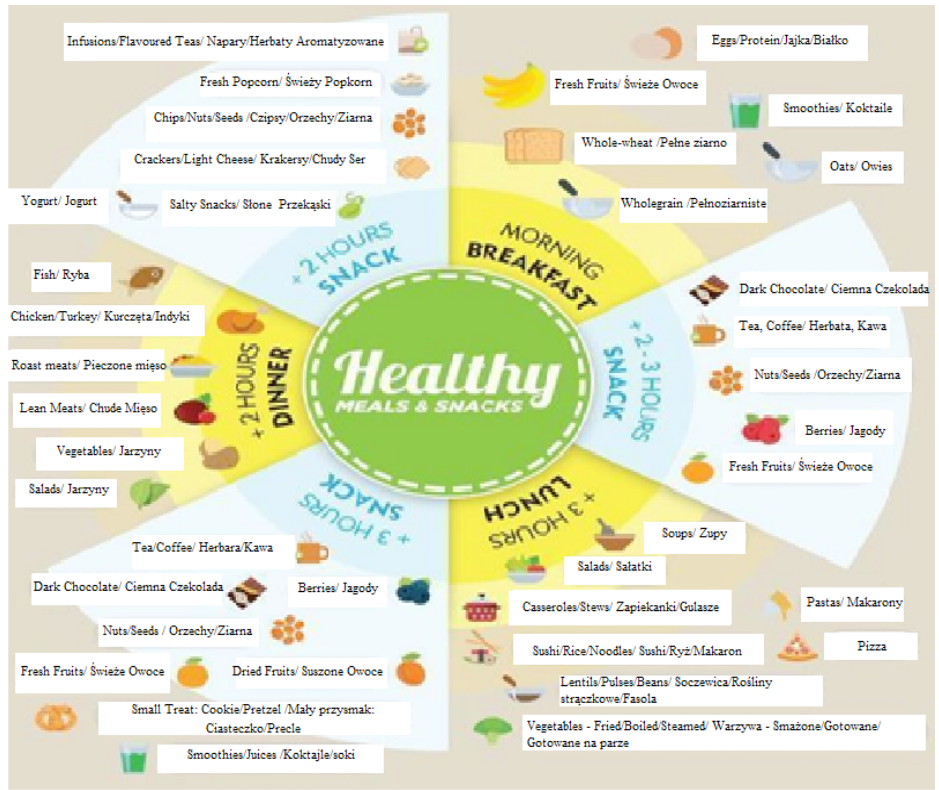

\section{WYKRES WSKAZÓWEK DOTYCZĄCYCH GŁODU}

Powinieneś spróbować zjeść, zanim dojdziesz do 3, najlepiej jeść między 4 a 6 . Kiedy dojdziesz do 7, powinieneś dążyć do zaprzestania jedzenia.

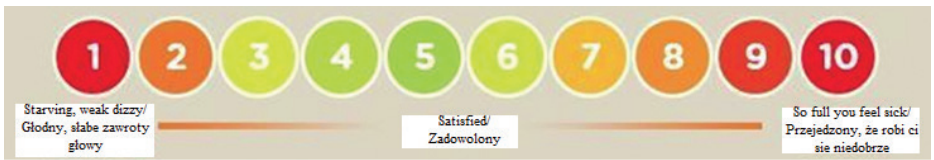

Po kilku dniach spożywania małych, zdrowych posiłków i przekąsek zauważysz, że Twój apetyt szybko reaguje na odpowiednie sygnały.
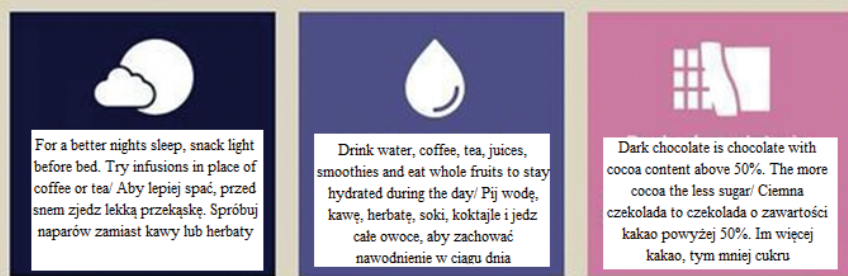

Rys. 1. Jak często powinniśmy spożywać posiłki, w tym przekąski

Fig. 1. How often meals including snacks should be eaten

Źródło/Source: (Internet 3). 
zująca się większą częstotliwością lub ilością spożywanych przekąsek wykazywała znacznie wyższy pobór błonnika pokarmowego i energii całkowitej oraz niższy pobór nasyconych kwasów tłuszczowych (SFA). Dlatego też jakość diety, oceniana na podstawie wyniku Simple Dietary Quality Index (Wskaźnik jakości diety, SDQI), nie była niższa u tych, którzy spożywali największą ilość kalorii w formie przekąsek (big snackers).

Badania przeprowadzone wśród dorosłych Francuzów (powyżej 18 roku życia) wykazały, że spożywanie przekąsek jest powszechne (Si Hassen i in., 2018). Przekąski spożywane rano były bardziej zdrowe od tych popołudniowych i wieczornych. Przekąski obejmowały nie tylko produkty żywnościowe i składniki odżywcze, których spożycie powinno być ograniczone, ale także te zalecane dla zdrowej diety, jak np. owoce. Przekąski takie jak produkty tłuste, słodkie, owoce, gorące napoje i chleb dostarczały najwięcej kalorii. Wiedza na temat wpływu zachowań żywieniowych związanych ze spożywaniem przekąsek na masę ciała i stan zdrowia ma kluczowe znaczenie dla określenia działań publicznych w zakresie promowania zdrowych nawyków żywieniowych.

Spożywanie przekąsek stało się zjawiskiem globalnym. Preferencje smakowe co do przekąsek różnią się w zależności od regionu czy państwa. Na przykład w przypadku Azji i Pacyfiku czekolada znalazła się na szczycie listy w Chinach, podczas gdy w Indiach były to chleb i przekąski kanapkowe. W Ameryce Łacińskiej jogurt był najpopularniejszą przekąską w Meksyku i Kolumbii, a lody - w Peru i Chile. Podczas gdy Francuzi wykazywali silną skłonność do produktów mlecznych, mieszkańcy Północnej Ameryki preferowali słone przysmaki. Natomiast zwolennicy zdrowych przekąsek z Izraela i Rumunii woleli spożywać owoce i warzywa (Monikantarajan, 2014). Według cytowanej autorki przeprowadzone przez Nielsen N.V (NYSE: NLSN) internetowe badania ankietowe wykazały, że ponad $75 \%$ respondentów spożywało przekąski, aby zaspokoić głód lub pragnienie między posiłkami. Niektórzy respondenci spożywali przekąski jako alternatywę posiłku, a inni dla czystej przyjemności smaku, aby poprawić swój nastrój, spędzić przyjemnie czas na przerwie, w nagrodę, a czasem po to, aby kontrolować swoją masę ciała. Jak zauważono, słone przekąski są nadal bardzo popularne wśród mieszkańców Ameryki. Jednakże w miarę jak wzrasta prozdrowotna świadomość konsumentów, przy równoczesnym szybkim tempie ich życia, zdrowe przekąski i przekąski w formie batonów (zbożowe, muesli, z orzechami, z nasionami, mięsne) umacniają swoją pozycję na rynku.

Pojęcie „przekąski” jest trudne do zdefiniowania. Spożywanie pokarmów lub napojów kalorycznych pomiędzy regularnymi posiłkami i motywacja do spożywania przekąski zależą od czynników zewnętrznych, takich jak m.in. pora dnia, rodzaj pożywienia, dostępność żywności i lokalizacja (Hess, Jonnalagadda i Slavin, 2016). $\mathrm{Z}$ dokonanego przez tych autorów przeglądu literatury wynika, że wpływ częstego jedzenia na wyniki zdrowotne, w tym przyrost masy ciała, pozostaje w dużej mierze nieznany. Sugeruje się, że spożywanie przekąsek ubogich w składniki odżywcze może być związane z wysokim BMI, jedzeniem bez poczucia głodu, jedzeniem poza 
domem lub pracą, modelowaniem społecznym i brakiem bezpieczeństwa żywnościowego. Mimo że czynniki te mogą być związane z nieprawidłowymi wyborami żywieniowymi w niektórych populacjach, motywacja do spożywania przekąsek, jak również wpływ przekąsek na zdrowie podlegają znacznym różnicom indywidualnym. Ponieważ mocno solone, słodzone i wysokotłuszczowe produkty żywnościowe, takie jak chipsy, desery i napoje słodzone cukrem, są nadal najpopularniejszymi przekąskami w wielu krajach, wytyczne żywieniowe mogą zmienić wyobrażenie o przekąskach, aby zapobiec sytuacji, w której „czas na przekąski” stanie się okazją do nadmiernego objadania się pokarmami ubogimi w składniki odżywcze.

Według Research and Markets' Healthy Snack Market Analysis, globalny rynek zdrowych przekąsek ma osiągnąc 32,8 mld USD do 2025 roku. Producenci, wychodząc naprzeciw żywieniowym oczekiwaniom konsumentów w odniesieniu do przekąsek, muszą spełnić dodatkowo nowe standardy zdrowotne uwzględniające np. czyste etykiety (clean label; termin podkreślający, że produkt jest naturalny i nie zawiera sztucznych dodatków), surowce niemodyfikowane genetycznie, produkty bezglutenowe oraz o niskiej zawartości cukru (Stephens, 2018).

\section{Przekąski mięsne oferowane przez przemysł mięsny na świecie}

Na przełomie lat siedemdziesiątych i osiemdziesiątych ubiegłego wieku przekąski mięsne dopiero zaczynały być wprowadzane do obrotu handlowego w USA i w Kanadzie. W tym czasie można było kupić tylko pokrojone i uformowane produkty z suszonego mięsa wołowego pod wspólną nazwa beef jerky oraz pałeczki kiełbasiane (sausage sticks). Firma International Meat Snack Sourcing, LLC produkuje przekąski o różnych smakach Canyon Country Beef Jerky z plastrów wołowiny, które po marynowaniu poddaje się wolnej obróbce cieplnej (Internet 1).

$\mathrm{Na}$ świecie można znaleźć wiele przekąsek mięsnych, w tym różnego rodzaju szynki (jak szynka parmeńska, szynka Bunderfleisch, Tillman’s Toasty), kiełbaski (np. kiełbaski BiFi) czy suszony bekon. Wiele przekąsek mięsnych ma podobną technologię wytwarzania, ale produkty te, w zależności od regionu, występują pod różnymi nazwami, a do najpopularniejszych z nich należą: beef jerky, qwanta, biltong, bakkwa oraz kilishi (Kuchlewska, 2019).

W przemysłowej produkcji beef jerky wykorzystuje się zarówno wołowinę, wieprzowinę, drób, dziczyznę (łoś, renifer, karibu, bizon), ryby (łosoś, tuńczyk), jak i mięso zwierząt egzotycznych (struś, aligator) (Krzywiński i Tokarczyk, 2011). Mięso tnie się na paski, następnie pekluje (marynuje), wędzi, suszy i pakuje. Profil smaku stanowi kombinację różnego rodzaju marynaty z wybranym gatunkiem mięsa. Wytwarzane są również produkty jerky ekstrudowane na bazie mięsa rozdrobnionego z dodatkiem substancji wiążących (np. mąka kukurydziana lub ziemniaczana) (Krzywiński i Tokarczyk, 2010). Na rynku obecne są także produkty typu jerky zawierające kofeinę, dostępne m.in. w sklepach sportowych, a ich oferta skierowana jest zwłaszcza do ludzi młodych, prowadzących aktywny tryb życia. Wytwarzane 
przemysłowo przekąski typu jerky zawierają ok. 15\% wody oraz nieznaczną ilość soli peklującej (9,1\%) a ich pH wynosi 3,5-4 (Kuchlewska, 2019). Znane są też inne suszone przekąski, np. qwanta (chuda wołowina lub jagnięcina; popularne w Etiopii, wschodniej Afryce), biltong (chuda wołowina, mięso antylopy, słonia, strusia; Brazylia, Afryka Południowa), bakkwa, zwana także gua lub rougan (z mięsa wieprzowego, drobiowego, kaczki, a nawet soi, w bardziej egzotycznym wydaniu - z krokodyla, emu, strusia, krewetek czy homara; Malezja, Singapur, Filipiny, Tajwan, Chiny), kilishi (chuda wołowina, baranina lub mięso kozie; Nigeria) (Kuchlewska, 2019).

\section{Przekąski mięsne oferowane przez przemysł mięsny w Polsce}

W Polsce już w 2004 roku na wzrastające zainteresowanie przekąskami mięsnymi zwrócili uwagę Konieczny, Kowalski i Pyrcz (2004). Autorzy ci przebadali dwa rodzaje importowanych z USA oryginalnych produktów przekąskowych z mięsa wołowego, tj. Beef Jerky Original (przekąska wołowa o oryginalnym smaku) i Beef Jerky Sweet \& Hot (przekąska wołowa o smaku słodko-pikantnym). Wykazali, że przekąski te charakteryzowały się swoistymi, zbliżonymi cechami jakościowymi, dobrą oceną sensoryczną i odpowiednią trwałością przechowalniczą.

Jak wskazują eksperci, kategoria przekąsek mięsnych w Polsce jest stosunkowo młodym, ale dynamicznie rozwijającym się segmentem całego rynku mięsa - wielu producentów rozbudowuje asortyment przekąsek, opracowując zarówno wyroby nawiązujące do tradycji, jak i zaskakujące innowacjami. Oferta przekąsek mięsnych jest bogata, a liderem w tej kategorii są kabanosy, będące produktem tradycyjnym, ale w nowej odsłonie, dostosowanej do bieżących oczekiwań konsumentów.

Przekąski mięsne dostarczają niezbędnych składników odżywczych, w tym pełnowartościowego białka, stanowią skondensowane źródło energii, zajmują mało miejsca $\mathrm{w}$ porównaniu z tradycyjną paczką chipsów (przy tej samej gramaturze) i mogą stanowić wartościowe uzupełnienie codziennej diety (Kuchlewska, 2019). Trzeba je jednak polubić, trzeba też umieć wybrać pomiędzy tanimi przekąskami typu fast food a droższymi przekąskami mięsnymi.

Producenci mięsnych przekąsek muszą mieć na uwadze nie tylko zmieniające się gusta konsumentów, możliwość zmiany ich nawyków żywieniowych, ale też szereg praktycznych problemów, które trzeba rozwiązać w kontekście stosownego opakowania produktu, gramatury, akceptowalnego terminu przydatności do spożycia czy możliwości przechowywania poza łańcuchem chłodniczym.

Czy zatem istnieją ograniczenia w zakresie popularności i dynamicznego rozwoju rynku przekąsek mięsnych w Polsce i na świecie? Czy można wskazać na jedynie chwilowe zafascynowanie konsumentów nowością przekąsek mięsnych, np. typu kabanosy, czy może powstaną inne, nowe przekąski i czy mają one potencjalnego konkurenta na współczesnym rynku?

Zanim znajdziemy odpowiedź na powyższe pytania, za Kuchlewską (2019) warto wskazać na fenomen przekąsek w kategorii kabanosy. To cienkie, długie kiełba- 
ski starannie wysuszone i uwędzone, których nazwa pochodzi od tureckiego słowa „kaban” oznaczającego wieprza. Zwyczajowo były one produkowane z peklowanego mięsa wieprzowego, ale obecnie na rynku dostępnych jest wiele wariantów tej niezwykle popularnej przekąski. Do podstawowych kryteriów podziału kabanosów przez konsumentów należą: rozmiar (klasyczne lub cienkie), surowiec, z którego są produkowane (wieprzowe, drobiowe, cielęce, wołowe, z indyka), smak (np. łagodne, pikantne), a także format opakowania (familijne lub impulsowe), co przekłada się na okoliczności ich spożywania.

Specyficzny charakter kabanosów wynika z kilku charakterystycznych dla tego produktu cech: kruchości, soczystości i specyfiki mięsa, wyjątkowego smaku i zapachu oraz jednolitego, charakterystycznego kształtu. Wyróżniającą cechą tradycyjnych kabanosów jest wyraźnie słyszalny w momencie ich przełamywania dźwięk trzasku („strzału”), będący efektem kruchości mięsa i odpowiedniego przygotowania tych wyrobów, zwłaszcza ich suszenia i wędzenia. Niepowtarzalny smak i zapach kabanosów to wynik zastosowania $\mathrm{w}$ procesie produkcji odpowiednio dobranych przypraw (jak pieprz naturalny, gałka muszkatołowa, kminek, cukier) $\mathrm{i}$ ich proporcji oraz właściwego procesu wędzenia. Specyficzny charakter wyrobów związany jest również z ich jednolitym, niepowtarzalnym kształtem - są to długie, cienkie batony suchej kiełbasy, odkręcone z jednej strony i równomiernie pomarszczone, złożone na pół i mające w przegięciu ślad po odwieszeniu (Kuchlewska, 2019).

Obecnie wiele firm posiada kabanosy w swojej ofercie i są to wyroby zarówno tradycyjne - cienkie kiełbaski w jelicie baranim, o wyraźnym smaku gałki muszkatołowej, kminku i wędzenia, jak i inne - bardzo cienkie, w różnych wariantach smakowych. Produkty te niezmiennie wyróżniają wysoka jakość i oryginalne kompozycje przypraw, w tym np. smaki typowe dla krajów słynących z doskonałej kuchni (kabanosy włoskie, francuskie itp.). Producenci oferują także kabanosy w bułce, paluszki kabanosowe oraz minikabanoski (Kuchlewska, 2019).

Inne mięsne przekąski obecne na polskim rynku to m.in.: pakowane pojedynczo parówki, minikiełbaski o różnych kształtach i smakach, kiełbaski koktajlowe, pieczone batoniki z różnych mięs z dodatkami, minisalami, jerky, stripsy (suszone paski z szynki), chipsy bekonowe i mięsne (wołowe, wieprzowe) w różnych smakach, Ofertę uzupełniają miniparóweczki z sosem pomidorowym oferowane m.in. w kubeczku z wieczkiem i widelczykiem (Jakubowska i Wierzejski, 2015; Kuchlewska, 2018). Innym wariantem mięsnej przekąski są kawałki kurczaka, jak skrzydełka czy panierowane kulki, nuggetsy, wykonane z mięsa drobiowego, które smakują także na zimno i nie wymagają wcześniejszego smażenia.

Specjalne linie produktów są też dedykowane dla najmłodszych amatorów mięsnych przekąsek - dzieci i młodzieży. W tej ofercie znajdują się m.in. kabanoski z dodatkiem cielęciny i indyka, charakteryzujące się szczególnie delikatnym smakiem, oraz przekąski będące połączeniem kabanosów i paluszków serowych, produkowane w kilku wariantach smakowych.

Konsumenci kupić mogą także miksy przekąsek składające się np. z różnych rodzajów wędlin ułożonych na tackach, często połączonych z serami lub piklami. Takie 
zestawy stanowią gotowe rozwiązanie na konkretne okazje - jako przystawki, dodatki do głównego posiłku, przekąski na spotkania towarzyskie czy piknikowe wyjazdy.

Wśród wymienionych przekąsek mięsnych odnaleźć można produkty bezglutenowe, bez dodatku fosforanów, glutaminianu sodu czy sztucznych barwników, również o obniżonej zawartości soli i tłuszczu (zwłaszcza produkty dedykowane dla dzieci). Charakteryzuje je niezmiennie wysoka mięsność i zawartość białka (Kuchlewska, 2019).

\section{Zakończenie}

Konsument podejmuje, jak się wydaje, racjonalne wybory dotyczące wielu produktów żywnościowych, w tym przekąsek. Ilość przekąsek na rynku zwiększa się z każdym rokiem i dlatego dokonując zakupów tego rodzaju produktów, należy koniecznie zapoznać się z ich składem podanym na etykiecie. Posiadanie aplikacji „Zdrowe Zakupy" powinno pomóc w dokonywaniu prawidłowych zakupów żywieniowych. Decyzje zakupowe powinny też opierać się na wiedzy konsumentów pozyskanej głównie w czasie edukacji szkolnej, a uzupełnionej informacjami ze środków masowego przekazu.

W pracy wskazano na różne podziały przekąsek, w tym wymieniono m.in. te, które jako wartościowe są zalecane do spożycia.

Spożywanie przekąsek niepełnowartościowych, mogących mieć negatywny wpływ na zdrowie, jest problemem nie tylko Polaków. To zjawisko ogólnoświatowe. Przemysł żywnościowy oferuje konsumentom coraz to nowsze produkty, a oni powinni dokonywać surowej selekcji tego, co kupują. Nie oznacza to jednak, że w purytański sposób trzeba podchodzić do zakupów przekąsek. Można wypróbować wszystkie, ale w taki sposób, aby się od nich nie uzależnić, bez względu na to, czy dotyczy to dzieci, młodzieży, czy seniorów. Każdy powinien zachować zdrowy rozsądek, ale ostatecznie podążać za zaleceniami żywieniowymi preferującymi warzywa i owoce oraz produkty jak najmniej przetworzone.

\section{Literatura}

Bąkowska, A. M., Nijaka, E. i Strażyńska, A. (2019). Porównanie jakości przekąsek warzywnych. W: W. Truszkowski, P. R. Sosna (red.), Uwarunkowania bezpieczeństwa i jakości żywności w Polsce. Olsztyn. Pobrane z http://www.uwm.edu.pl/kpros/images/monografie/M_BZ.pdf

Bo, S., De Carli, L., Venco, E., Fanzola, I., Maiandi, M., De Michieli, F., Durazzo, M., Beccuti, G., Cavallo-Perin, P., Ghigo, E. i Ganzit, G. (2014). Impact of snacking pattern on overweight and obesity risk in a cohort of 11- to 13-year-old adolescents. Journal of Pediatric Gastroenterology and Nutrition, 59(4), 465-471. Pobrane z https://journals.lww.com/jpgn/Fulltext/2014/10000/Impact_of_Snacking_Pattern_on_Overweight_and.11.aspx

Górnicka, M., Frąckiewicz, J., Anyżewska, A. i Brzezińska, A. (2016). Warzywa i owoce w 326 przedszkolnych jadłospisach. Problemy Higieny i Epidemiologii, 97(1), 76-80. 
Hess, J. M., Jonnalagadda, S. S. i Slavin, J. L. (2016). What is a snack, why do we snack, and how can we choose better snacks? A review of the definitions of snacking, Motivations to snack, contributions to dietary intake, and recommendations for improvement. Advances in Nutrition, 7(3), 466-475. Pobrane z https://www.ncbi.nlm.nih.gov/pmc/articles/PMC4863261/

Hynek-Okonski M. (2007). Zdrowe przekąsi w czasie odchudzania, PMS, miesiaczki, stresu, uprawiania sportu. Pobrane z https://www.poradnikzdrowie.pl/diety-i-zywienie/odchudzanie/zdroweprzekaski-w-czasie-odchudzania-pms-miesiaczki-stresu-uprawiania-aa-LjkN-foFM-iE3T.html

Jakubowska, D. i Wierzejski, T. (2015). Potencjał rozwoju rynku produktów z suszonego mięsa wołowego w Polsce na przykładzie przekąsek wołowych typu „BeefJerky”. Marketing i Rynek, 2, 255-267. Pobrane z https://www.researchgate.net/publication/279847722_Potencjal_rozwoju_rynku produktow_z_suszonego_miesa_wolowego_w_Polsce_na_przykladzie_przekasek_wolowych_ typu_Beef_Jerky

Kazbieruk, M. (2020). Zdrowe przekąski - witaminy, stonecznik, winogrona, jogurt, jabłka, wafle ryżowe, marchew. Pobrane z https://zywienie.abczdrowie.pl/zdrowe-przekaski

Konieczny, P., Kowalski, R. i Pyrcz, J. (2004). Wybrane wyróżniki jakościowe suszonych produktów przekąskowych z mięsa wołowego. Żywność, Nauka, Technologia, Jakość, 11(3), 32-39.

Kosicka-Gębska, M. i Gębski, J. (2012). Słone przekąski w diecie młodych konsumentów. Bromatologia Chemia Toksykologiczna, XLV(3),733-738. Pobrane z https://ptfarm.pl/pub/File/Bromatologia/2012/3/733-738.pdf

Krzywiński, T. i Tokarczyk, G. (2010). Tradycyjne i niekonwencjonalne przekąski mięsne. Przemyst Spożywczy, 3, 16-19.

Krzywiński, T. i Tokarczyk, G. (2011). Przekąski mięsne w Polsce i na świecie. Gospodarka Mięsna, 3, 28-34.

Kuchlewska, M. (2018). Mięso i jego przetwory jako żywność wygodna. Ogólnopolski Informator Masarski, 277(09), 12-32. Pobrane z https://informatormasarski.pl/wp-content/wydania/IM_277_ wrzesien\%202018.pdf

Kuchlewska, M. (2019). Przegląd przekąsek mięsnych - Polska i świat. Ogólnopolski Informator Masarski, 291(11), 36-47.

Kulshrestha, S., Pant, U. i Kulshrestha, S. 2017. Nutrition in adolescence - Issues and challenges for health. Pobrane $\mathrm{z}$ http://www.academia.edu/7144378/NUTRITION IN ADOLESCENCE ISSUES_AND_CHALLENGES_FOR_HEALTH

Lamont, M. (2018). Zdrowe jedzenie w biegu - jak zorganizować petnowartościowe positki? Pobrane z https://kcalmar.com/blog/2018/02/05/zdrowe-jedzenie-w-biegu/

Mazowska, K. (2020). Przekąski - zdrowe przekąski, niezdrowe przekąski, kaloryczność, wybór. abcZdrowie. Pobrane z https://zywienie.abczdrowie.pl/zdrowe-i-smaczne-przekaski

Monikantarajan, M. (2014). Snackistics around the world. Pobrane $\mathrm{z}$ https://memoirsofmonisha.wordpress.com/2014/12/13/snackistics-around-the-world/

Nicklas, T. A., O’Neil, C. E. i Fulgoni, V. L. (2013). Relationship between snacking patterns, diet quality and risk of overweight and abdominal obesity in children. International Journal of Child Health and Nutrition, 2, 189-200. Pobrane z https://www.lifescienceglobal.com/media/zj_fileseller/files/ IJCHNV2N3A1-Nicklas-OA.pdf

Si Hassen, W., Castetbon, K., Tichit, C., Péneau, S., Nechba, A., Ducrot, P., Lampuré, A., Bellisle, F., Hercberg, S., Méjean, C. (2018). Energy, nutrient and food content of snacks in French adults. Nutrition Journal, 17(1), 33.

Stephens, K. (2018). Global snacking trends. Pobrane z https://www.naturalproductsinsider.com/foods/ global-snacking-trends

Wang, D., Van der Horst, K., Jacquier, E. F., Afeiche, M. C. i Eldridge, A. L. (2018). Snacking patterns in children: A comparison between Australia, China, Mexico, and the US. Nutrients, 10(2), 198. Pobrane z https://www.mdpi.com/2072-6643/10/2/198/htm 


\section{Źródla elektroniczne}

Internet 1. http://intlmss.com/ecommerce/category.i?catid=1) (dostęp: 19.03.2021).

Internet 2. https://jestemkobieta.com/2018/11/13/rola-przekasek-w-zdrowym-zywieniu/ (dostęp: 19.03.2021).

Internet 3. https://nutritionbookblog.wordpress.com/2017/04/01/snacking-pattern-of-adolescents/ (dostęp:19.03.2021).

Internet 4. http://ptnz.sggw.pl/wp-content/uploads/2017/07/2015_Przekaski_stanowisko_ekspertow. pdf (dostęp: 19.03.2021).

Internet 5. https://www.diagnostic.org.pl/cele-przeprowadzania-badan-rynku-chipsow/ (dostęp: 19.03.2021)

Internet 6. https://www.portalspozywczy.pl/slodycze-przekaski/wiadomosci/zdrowe-przekaski-corazwazniejsze-w-diecie-polakow,109710.html (dostęp: 19.03.2021). 